\title{
Approach to Ventricular Arrhythmias in the Pediatric Intensive Care Unit
}

\author{
Jong-Hau Hsu, Jiunn-Ren $\mathrm{Wu}^{*}$, Zen-Kong Dai and I-Chen Chen \\ Department of Pediatrics, Kaohsiung Medical University Hospital and College of \\ Medicine, Kaohsiung Medical University, Kaohsiung,
}

Taiwan

\section{Introduction}

Ventricular arrhythmia was once regarded uncommon in infants and children, since most cardiac arrests were thought to be hypoxia-induced bradycardia followed by asystole. Furthermore, ischemic heart disease, the basis for many of the ventricular arrhythmias in adults, is rare in pediatric patients. However, with the advent of pediatric critical care, improved techniques of extracorporeal life support, increasing awareness of genetic abnormalities, and a growing population of patients with congenital heart diseases, ventricular arrhythmia is being recognized more frequently in pediatric patients, and is becoming a larger management issue.

Pediatric critical care is a special field that rapid diagnosis and intervention are often essential. These interventions may be life-saving or sometimes debilitating, depending on their appropriateness and timeliness. The spectrum of cardiac arrhythmias in the pediatric intensive care unit (PICU) ranges from those that are immediately life threatening to those with little or no hemodynamic consequences. However, patients in the PICU often have hemodynamic instability, poor cardiac reserve or structural cardiac defects so that they are especially vulnerable to arrhythmia-induced cardiac dysfunction. Therefore, early recognition and prompt management of life-threatening ventricular arrhythmias are essential aspects of the care that must be provided to these patients. Indeed, given with the heterogeneity of diseases and complexity of structural heart defects in the pediatric critical care setting, treatment must frequently be provided in the PICU even before the specific cardiac diagnosis is made. To meet this challenge, the management of life-threatening ventricular arrhythmias in children will be the most effective if these arrhythmias are anticipated by the pediatric intensivist.

The aims of this chapter are to provide an update, from the standpoint of pediatric critical care, regarding comprehensive concepts of (1) non-cardiac clinical entities associated with ventricular arrhythmias, such as electrolyte imbalance, hypothermia, infection and drugs; (2) cardiac entities associated with ventricular arrhythmias, such as dilated cardiomyopathy, hypertrophic obstructive cardiomyopathy, and congenital heart diseases post cardiac surgery;

${ }^{*}$ Corresponding Author 
(3) genetic abnormalities associated with ventricular arrhythmias, including conditions such as long QT syndrome, arrhythmogenic right ventricular cardiomyopathy, and Brugada syndrome; and (4) management of ventricular arrhythmias in the PICU.

\section{Non-cardiac clinical entities associated with ventricular arrhythmias}

In a multidisplinary PICU, although it is appropriate to consider ventricular arrhythmias as a problem of cardiac origin, other noncardiac etiologies should not be overlooked. Table 1 shows the systemic causes of ventricular arrhythmias.

\begin{tabular}{|l|l||}
\hline Electrolyte imbalance & $\begin{array}{l}\text { Hyperkalemia } \\
\text { Hypokalemia } \\
\text { Hypomagnesemia } \\
\text { Hypocalcemia }\end{array}$ \\
\hline Hypothermia & $\begin{array}{l}\text { Cold stress } \\
\text { Therapeutic hypothermia } \\
\text { Extracorporeal life support }\end{array}$ \\
\hline Infectious & $\begin{array}{l}\text { Systemic viral infections causing myocarditis } \\
\text { Systemic bacterial infections causing endocarditis } \\
\text { Sepsis-induced cardiomyopathy }\end{array}$ \\
\hline & $\begin{array}{l}\text { Catecholamine } \\
\text { Quinidine } \\
\text { Procainamide } \\
\text { Digitalis } \\
\text { Psychotropic medications }\end{array}$ \\
\hline Drugs & Displacement of central venous catheters \\
\hline Traumatic
\end{tabular}

Table 1. Systemic clinical entities associated with ventricular arrhythmia

\subsection{Electrolyte imbalance}

Serum electrolyte imbalance is very common in patients in the PICU for many non-cardiac reasons. Potassium is the one with the greatest chances to cause ventricular arrhythmias (Schaefer et al., 2005). For, example, we have previously demonstrated a case of lifethreatening ventricular arrythmias and hyperkalemia induced by tumor lysis syndrome during the surgical biopsy (Lee et al., 2007). Hyperkalemia causes electrocardiographic changes before it reaches the serum potassium levels that cause arrhythmia. With modest hyperkalemia, the T wave will become narrow and peaked. Pediatric patients with faster resting heart rates tend to have narrower $\mathrm{T}$ waves, and peaked $\mathrm{T}$ waves may not be immediately evident. The QRS widens with higher levels of potassium. With extremely high serum potassium, ventricular tachycardia and fibrillation will ultimately occur. Hypokalemia causes prolonged QT-U interval and prominent $U$ waves. Although less common than hyperkalemia, hypokalemia may also induce polymorphic ventricular tachycardia or ventricular fibrillation. Different from the devastating effect of potassium, imbalance of serum calcium and magnesium rarely cause significant arrhythmia.

\subsection{Hypothermia}

Hypothermia can slow the rate of sinus rhythm induce ventricular arrhythmia. Mild hypothermia results in the development of QT interval prolongation. Deep hypothermia 
results in AV block and subsequently ventricular arrhythmia and fibrillation (Pilichou et al., 2006). With the emergence of hypothermia as a critical management in the ICU, such as to improve the outcome especially in the survivors of out-of-hospital cardiac arrest and neonatal asphyxia, ventricular arrhythmia can be a growing issue to be concerned. Indeed, recent case reports have demonstrated occurrences of ventricular tachycardia, fibrillation, and Torsade de pointes during the procedure of hypothermia (Schaefer et al., 2005; Matsuhashi et al., 2010), suggesting that monitoring temperature levels is very important as the risk of life-threatening may induced by deep hypothermia less than $32^{\circ} \mathrm{C}$.

\subsection{Infection}

Systemic infection may cause sinus tachycardia due to an increase in metabolic demand. Endocarditis near the normal conduction system may cause AV block by direct damaging conduction system. Myocarditis, one of the most common pediatric acquired heart diseases, is often associated with ventricular tachyarrhythmia. Myocarditis may not always be the primary source of infection but may complicate systemic infection, such as viremia or viral encephalitis For example, enteroviral infection is one of the most common causes of fulminant myocarditis secondary to systemic infection in the setting of pediatric critical care (Figure 1.). Rheumatic heart disease, a complication of group A streptococcal infection, may cause transient or permanent AV block and sinus node dysfunction. Lyme disease, transmitted by the bite of a tick infected with Borrelia burgdorferi, is also known to cause AV block and other cardiac conduction abnormalities (Lo et al., 2003).

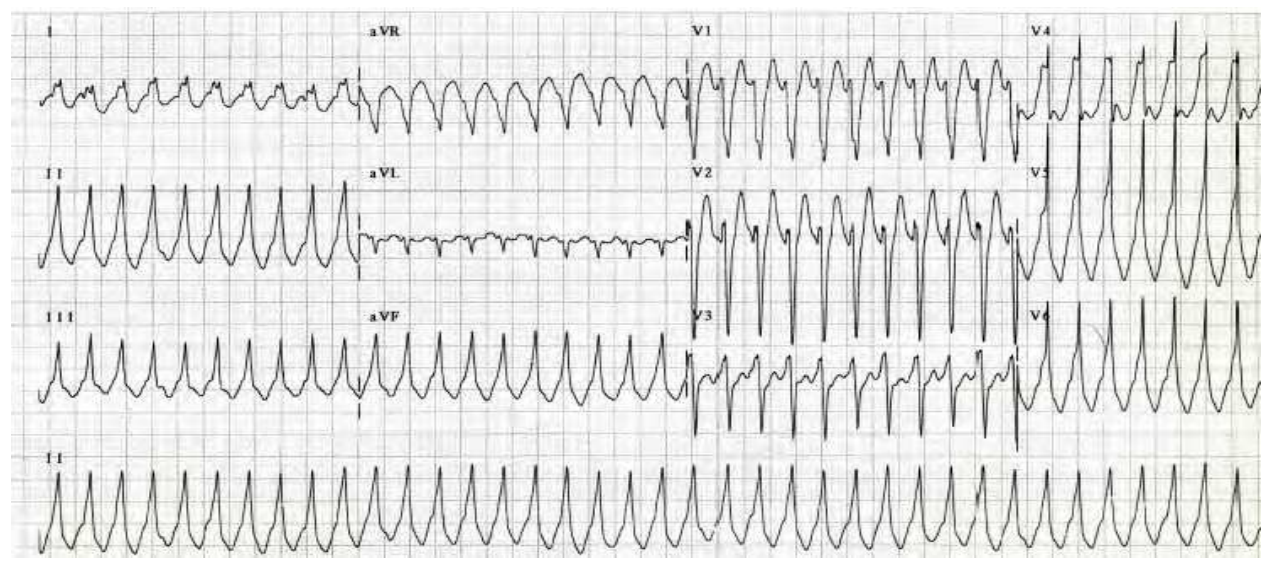

Fig. 1. EKG of ventricular tachycardia in a child with enteroviral encephalitis complicated with fulminant myocarditis.

\subsection{Drugs}

Drugs commonly administered in the PICU such as exogenous catecholamines, digoxin, and antiarrhythmic drugs may possess potential proarrhythmic effects. Although the arrhythmic effects of exogenous catecholamines are usually immediately recognized and treated, digoxin toxicity may be more difficult to be recognized due to its insidious effect. Renal 
function impairment in critically ill patients and administration of medications affecting digoxin metabolism are common in the PICU. Digitalis toxicity can result in many forms of arrhythmia. Treatment of digitalis toxicity has been simplified with the availability of digoxin-immune $\mathrm{Fab}$ antibody therapy. Toxicity with other antiarrhythmic drugs has become less frequent, such as the use of quinidine and procainamide.

\section{Cardiac entities associated with ventricular arrhythmias}

In the PICU, ventricular arrhythmias are often associated cardiac diseases. We herein discuss common cardiac diseases including dilated cardiomyopathy, hypertrophic cardiomyopathy and congenital heart diseases.

\subsection{Dilated cardiomyopathy}

Dilated cardiomyopathy (DCM) is the most common severe cardiomyopathy, accounting for more than $50 \%$ of pediatric cardiomyopathy (Jefferies et al., 2010). Etiology of DCM includes immunologic, familial, metabolic, infectious, toxic and neuromuscular causes. These patients are prone to ventricular arrhythmia. Treatment is targeted at symptoms, ventricular dysfunction and underlying rhythm disturbance. Prophylactic use of implantable cardiac defibrillator in the pediatric population is not well established as in adults with ischemic cardiomyopathies. In patients with muscular dystrophy, DCM is also common and may be a potential cause of mortality in these patients due to ventricular arrhythmia. Figure 3 shows non-sustained ventricular tachycardia and a premature ventricular contraction in a patient with Duchenne muscular dystrophy complicated with DCM.

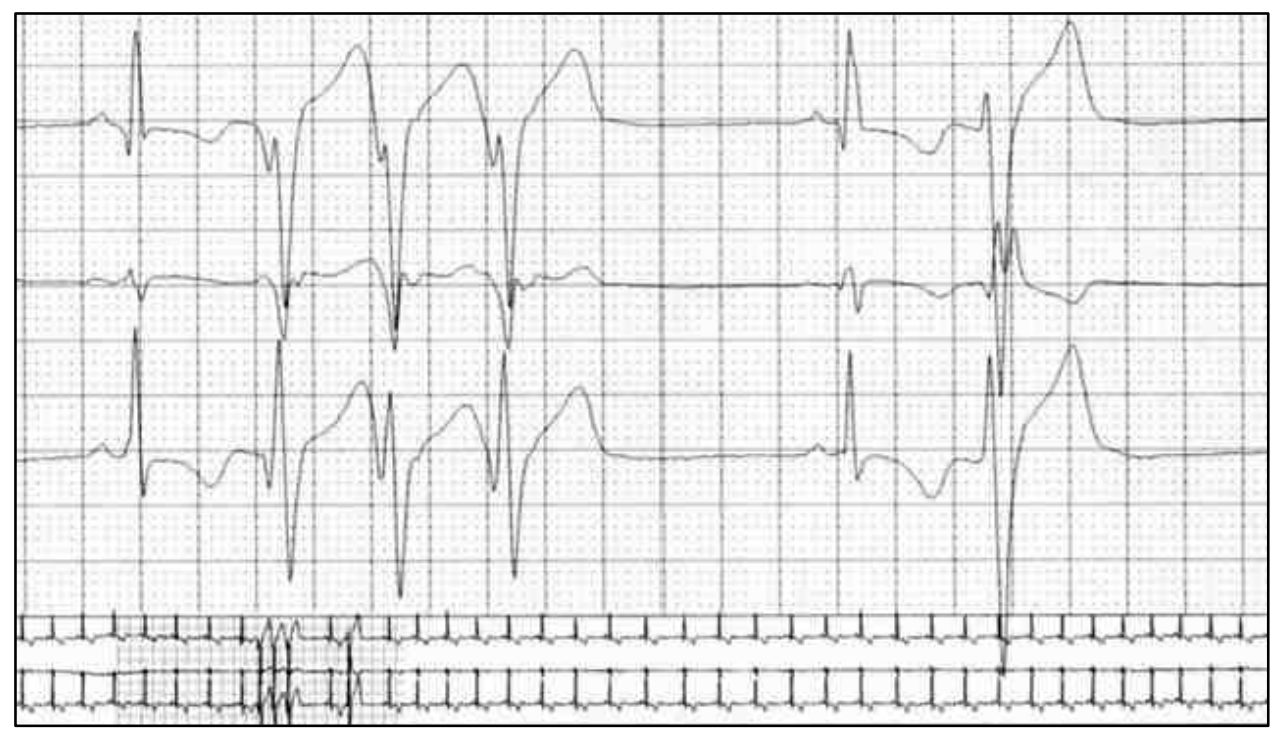

Fig. 2. A patient of Duchenne muscular dystrophy with dilated cardiomyopathy presented with chest pain. The Holter EKG record revealed non-sustained ventricular tachycardia and a premature ventricular beat. 


\subsection{Hypertrophic cardiomyopathy}

Patients with hypertrophic cardiomyopathy comprise a subgroup with myocardial disease that is prone to ventricular arrhythmias. Left ventricular outflow tract obstruction may cause coronary artery insufficiency and myocardial ischemia, thus resulting in ventricular arrhythmias. Microscopically, hypertrophic cardiomyopathy shows disorganization of the cardiac muscle cells, a substrate for arrhythmia. Indeed, this microscopic finding seems to put these patients at risk regardless of the degree of outflow tract obstruction. Non-sustained ventricular tachycardia is common in children with hypertrophic cardiomyopathy. Clinical risk factors of sudden death include family history of cardiac arrest, increased QRS duration, myocardial bridging of the left coronary artery, increased QT dispersion, ventricular wall thickness, exercise-induced hypotension, and syncope.

\subsection{Congenital heart disease post cardiac surgery}

Ventricular arrhythmia has a reported incidence of $1-5 \%$ among pediatric patients and adults who have had palliative surgery for congenital heart disease (CHD) (Gatzoulis et al., 2000; Deanfield et al., 1980; Vetter et al., 1982; Kavey et al., 1982). With the advent of surgical technique and postoperative care, ventricular arrhythmia and sudden death have been reported as causes of early, intermediate and late morbidity and mortality (Garson et al., 1979). Congenital heart diseases are associated with various types of arrhythmia, depending on specific lesions, as shown in Table 3.

\begin{tabular}{|l|l|}
\hline \multicolumn{1}{|c|}{ Congenital heart disease } & \multicolumn{1}{c|}{ arrhythmia } \\
\hline Tetralogy of Fallot & Atrial tachycardia \\
\hline Double outlet right ventricl & $\begin{array}{l}\text { Ventricular tachycardia } \\
\text { Sinus node dysfunction }\end{array}$ \\
\hline Transposition of the great arteries & $\begin{array}{l}\text { Ventricular arrhythmias } \\
\text { Atrioventricular block }\end{array}$ \\
\hline Ebstein's anomaly & Supraventricular tachycardia \\
\hline Ventricular septal defect repair & $\begin{array}{l}\text { Heart block } \\
\text { Ventricular arrhythmias }\end{array}$ \\
\hline Atrial septal defect & Atrial tachycardia \\
\hline Atrial septal defect repair & Sinus node dysfunction \\
\hline
\end{tabular}

Table 2. Congenital heart disease and associated arrhythmias

Occurrence of ventricular arrhythmia is particularly well known after the repair of tetralogy of Fallot (TOF). To relieve the obstruction of right ventricular outflow tract in TOF, it is always necessary for the surgeon to make a right ventricular outflow tract incision, to augment the outflow tract region, and repair the ventricular septal defect with a patch. Thus, the scar after surgical procedures may create a complex substrate for the development of arrhythmias.

Postoperative ventricular arrhythmias have been previously found in 5-10\% of patients on the 12-lead ECG and in 40-60\% on 24-hour Holter EKG in patients undergoing surgery (Garson et al., 1990). The advent of surgical techniques and repair at a younger age have led to a significant reduction in the incidence of arrhythmias. In fact, transatrial repair has been 
confirmed to have a beneficial effect on the incidence of ventricular arrhythmias. For example, a study comparing the incidence of arrhythmias in two groups of patients who underwent transventricular or transatrial repair showing that in the former group, 39.4\% had significant ventricular arrhythmias, while in the latter group only $2.8 \%$ had significant arrhythmias (Dietl et al., 1994).

In addition to ventricular arrhythmias, sudden cardiac death is also an important issue and has been reported in $1.5-5 \%$ of patients after repair of TOF. In fact, ventricular arrhythmias have been regarded as a controversial etiological factor of sudden cardiac death (Garson et al., 1980; Katz et al., 1982; Quattlebaum et al., 1975). For example, it has been reported that previous ventricular arrhythmias were found in $100 \%$ of patients who died suddenly, compared to $12 \%$ of those who did not (Garson et al., 1985). On the other hand, another study followed patients with TOF post surgery for 12 years and found no correlation between the degree of ventricular arrhythmias and sudden death (Cullen et al., 1994). Therefore, some studies were aimed to elucidate the relationship between ECG indices and the risk of ventricular tachycardia and sudden death. A QRS duration $>180 \mathrm{~ms}$ was found to be a very sensitive predictor for the development of VT and sudden death (Gatzoulis et al., 1995), so is the use of a transannular patch in combination with severe pulmonary valve insufficiency (Gatzoulis et al. , 2000). Furthermore, QT dispersion has also been suggested as risk factor of sustained ventricular tachycardia (Gatzoulis et al., 1997). Factors associated with the development of ventricular tachycardia in patients with TOF are summarized in Table 2.

\author{
Older age at repair \\ Earlier surgical era \\ Residual ventricular septal defect \\ Prior systemic-to-pulmonary artery shunt \\ Trans-annular right ventricular outflow tract patch \\ Right ventricular pressure overload \\ Right ventricular volume overload \\ Ventricular arrhythmias \\ Atrial arrhythmias \\ Complete heart block \\ QRS duration $>180$ mini-seconds
}

Table 3. Proposed risk factors for ventricular tachycardia and sudden death after repair of tetralogy of Fallot

Patients with other cardiac lesions may also be at risk for ventricular arrhythmias. Patients with aortic stenosis seem to be the highest risk group (Wolfe et al., 1993), with an increased mortality risk in patients with greater outflow tract gradients. Thus, all patients with repaired and unrepaired congenital heart disease should be considered at increased risk for ventricular arrhythmias and associated morbidity, including sudden death.

Notably, some atypical forms of supraventricular tachycardia can mimic ventricular tachycardia, such as supraventricular tachycardia with right bundle branch block after repair of TOF or double outlet of right ventricle (Figure 3). However, a wide QRS complex tachycardia in a patient who is hemodynamically unstable should be treated as ventricular tachycardia until proven otherwise. 

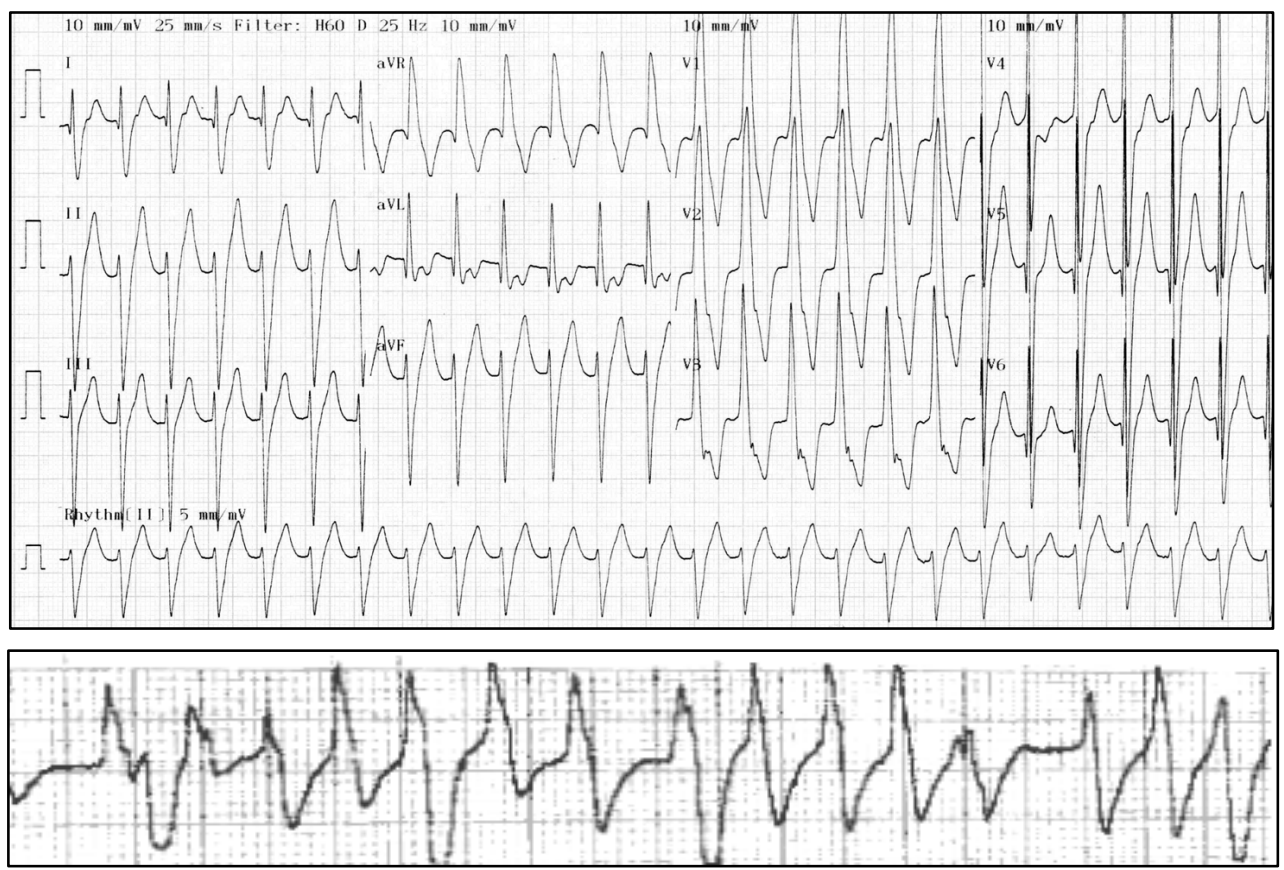

Fig. 3. Upper panel: The EKG of a patient with double outlet of right ventricle post palliative repair. Even with wide QRS, the inverted $p$ wave following every QRS in aVL suggests supraventricular tachycardia instead of ventricular tachycardia. Lower panel: Another episode of ventricular tachycardia recorded in the lead II EKG strip in the same patient.

\section{Genetic abnormalities associated with ventricular arrhythmias}

Various forms of genetic abnormality-associated with ventricular arrhythmia may place a child at risk for sudden cardiac death. Although some diseases are clinically obvious, cardiovascular collapse may be the first symptom in others. Studies of sudden cardiac death and ventricular arrhythmia have therefore focused on identification of patients with the genetic abnormalities, including long QT syndrome, arrhythmogenic right ventricular dysplasia and Brugada syndrome.

\subsection{Long QT syndrome}

The congenital long QT syndrome (LQTS) is a rare but important clinical disorder, with the prevalence of 1 to 2500 live births. It includes two hereditary variants under the unifying name of "Long QT syndrome" (Schwartz et al., 1975). One is associated with deafness, Jervell and Lange-Nielsen syndrome (Jervell et al., 1957; Schwartz et al., 2006), and one is not, Romano-Ward syndrome (Romano et al., 1963; Ward et al., 1964). Long-QT syndrome has been subdivided into types based on the gene in which causative mutations occur. The most prevalent forms are LQT1 and LQT2 (mutations in potassium channels), and LQT3 (mutation in a sodium channel). The clinical manifestations of the disease may be lifethreatening including syncope, cardiac arrest and sudden death. Electrocardiographic and genetic features of LQTS are discussed below. 


\subsubsection{Electrocardiographic features}

\subsubsection{QT interval duration}

The Bazett's correction for heart rate remains a very useful clinical tool. Conventionally, QTc values in excess of $440 \mathrm{~ms}$ are considered prolonged; however, values up to $460 \mathrm{~ms}$ may still be normal among females (Merri et al., 1989). The longer QT values among women and becoming evident only after puberty suggest a role for hormonal changes (Stramba et al., 1995). Even though syncope occurs also in patients with modest QT prolongation or even with a normal QT interval., however, it is believed that the longer the QT, the greater is the risk for malignant arrhythmias. In fact, when QTc exceeds 500-550 ms, there is a definite increase in risk (Priori et al., 2003; Moss et al., 1991)

\subsubsection{2 $\mathrm{T}$ wave morphology}

In LQTS both the duration of repolarization and its morphology are altered. The T wave is often biphasic or notched because of regional differences in the time course of ventricular repolarization, especially prominent in the precordial leads. (Figure 4)

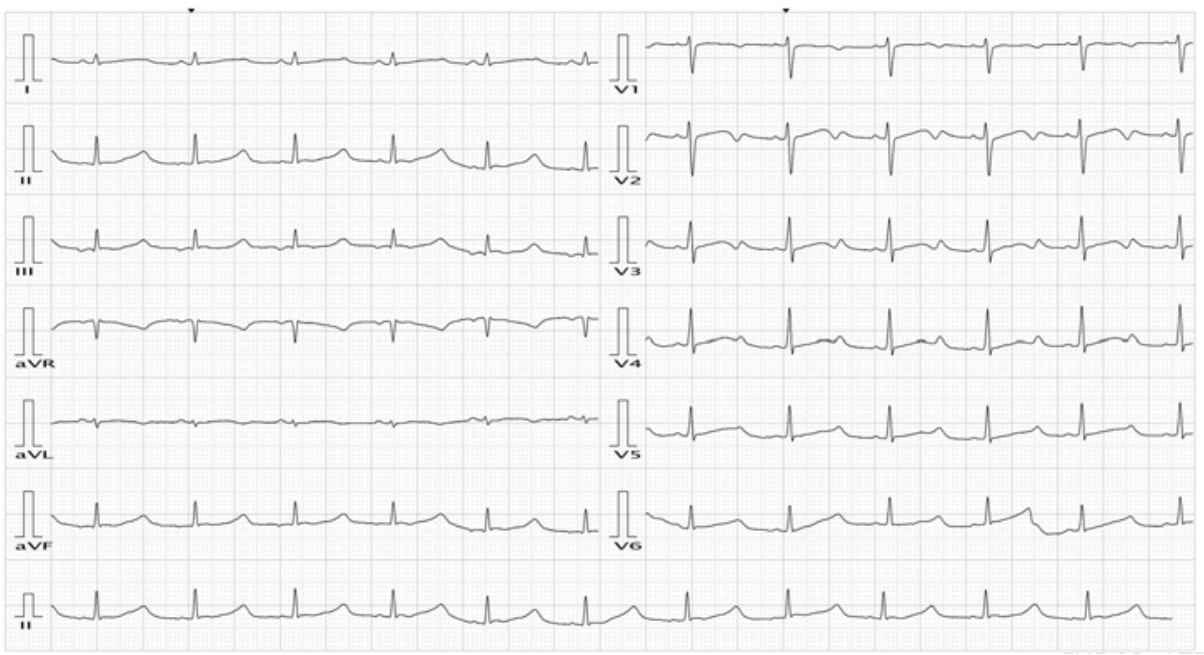

Fig. 4. The 12-lead EKG of a 13 year-old girl with long QT syndrome with the clinical presentation of recurrent syncopes. The QTc is $645 \mathrm{~ms}$, with typical biphasic T waves in $\mathrm{V} 2$ and V3.

\subsubsection{3 $\mathrm{T}$ wave alternans}

Beat-to-beat alternation of the $\mathrm{T}$ wave is a marker of electrical instability suggesting the diagnosis of LQTS. It may be present at rest but most commonly appears during emotional or physical stresses and may sometimes precede torsades de pointes.

\subsubsection{Sinus pauses}

Sudden pauses in sinus rhythm longer than 1.2 seconds that are not related to sinus arrhythmia may be present in LQTS patients and may contribute to the initiation of ventricular arrhythmias. Their occurrence in LQT3 patients represents an important warning signal that warrants further life-saving management. 


\subsubsection{Genetic etiologies of LQTS}

Since 1995, following the first identification of the first three LQTS genes associated with the most frequently encountered LQTS variants LQT1, LQT2, and LQT3, there has been growing identifications of genes associated with LQTS (Wang et al., 1995; Curran et al., 1995; Wang et al., 1996) including the genes for LQT4 through LQT10 (Table 3)

\begin{tabular}{|l|l|l|}
\hline LQTS subtypes & Gene & Prevalence (\%) \\
\hline LQT1 & KCNQ1 & 50 \\
\hline LQT1 & KCNQ1 & 35 \\
\hline LQT2 & KCNH2 & 10 \\
\hline LQT3 & SCN5A & $<5$ \\
\hline LQT4 & ANK2 & $<5$ \\
\hline LQT5 & KCNE1 & $<5$ \\
\hline LQT6 & KCNE2 & $<5$ \\
\hline LQT7 & KCNJ2 & $<5$ \\
\hline LQT8 & CACNA1c & $<5$ \\
\hline LQT9 & CAV3 & $<5$ \\
\hline LQT10 & SCN4B & $<5$ \\
\hline
\end{tabular}

Table 4. Long QT syndrome (LQTS) subtypes, disease-associated genes and prevalenc

\subsubsection{Association between sudden infant death syndrome and LQTS}

Sudden infant death syndrome (SIDS) is the leading cause of sudden death during the first year of life. The causes of SIDS remain a mystery, even with a lot of theories focused on dysfunctional control of respiratory or cardiac function (Schwartz et al., 1988). However, there are some evidence showing the association between SIDS and LQTS. For example, a large cohort study measuring the QT interval during the first week of life in more than 30,000 infants and following them for occurrence of SIDS demonstrated that infants who died of SIDS had a longer QTc than the survivors and the victims from other causes (Schwartz et al., 1998). In addition, in a study of Norway (Arnestad et al., 2007), based on 201 SIDS victims and 187 controls, mutations in LQTS genes were identified. These data justify the rationale of neonatal ECG screening and the guidelines proposed by the Task Force of the European Society of Cardiology (Schwartz et al., 2002) Therefore, future aim is the prevention of those sudden deaths due to unrecognized LQTS which may result in SIDS.

\subsection{Arrhythmogenic right ventricular dysplasia}

Arrhythmogenic right ventricular dysplasia (ARVD) is a predominantly genetically determined and heritable form of cardiomyopathy that may lead to right ventricular failure, ventricular arrhythmias, and sudden cardiac death. It is uniquely characterized by the replacement of myocytes by adipose and fibrous tissue in histology. The estimated prevalence of ARVD ranges from 1 in 2,000 to 1 in 5,000, with a predominance in men than women, with an approximate ratio of 3:1 (Corradoet al., 2006). Twelve genes have been identified to be associated with ARVD (Table 4). These genes are responsible for encoding several components of the cardiac desmosome. Dysfunctional desmosomes cause defective cell adhesion proteins, such as plakoglobin (JUP), desmoplakin (DSP), plakophilin-2 (PKP-2), and desmoglein-2 (DSG-2) consequently cause loss of electrical coupling between cardiomyocytes, leading to death of cardiomyocyte, fibrous replacement of myocardium and finally arrhythmias (Rampazzo et al., 2002 ; McKoy et al., 2000; Gerull et al., 2004; Pilichou et al., 2006). Diagnosis is 
based on the finding a combination of characteristic abnormalities in family history, electrocardiography, cardiac imaging especially MRI and biopsy.

\begin{tabular}{|l|l|l|l|}
\hline ARVD type & Chromosome/locus & Gene codes & Mode of transmission \\
\hline ARVD type 1 & $14 \mathrm{q} 23-\mathrm{q} 24$ & TGF $3-3$ & Autosomal dominant \\
\hline ARVD type 2 & $1 \mathrm{q} 42-\mathrm{q} 43$ & RyR2 & Autosomal dominant \\
\hline ARVD type 3 & $14 \mathrm{q} 12-\mathrm{q} 22$ & & Autosomal dominant \\
\hline ARVD type 4 & $2 \mathrm{q} 32$ & & Autosomal dominant \\
\hline ARVD type 5 & $3 \mathrm{q} 23$ & $\begin{array}{l}\text { Transmembrane protein } \\
\text { A } 3\end{array}$ & Autosomal dominant \\
\hline ARVD type 6 & $10 \mathrm{p} 12-\mathrm{p} 14$ & & Autosomal dominant \\
\hline ARVD type 7 & $10 \mathrm{q} 22$ & & Autosomal dominant \\
\hline ARVD type 8 & $6 \mathrm{p} 24$ & Desmoplakin(DSP) & Autosomal dominant \\
\hline ARVD type 9 & $12 \mathrm{p} 11$ & Plakophilin-2(PKP2) & Autosomal dominant \\
\hline ARVD type 10 & $18 \mathrm{q} 12$ & Desmoglein-2(DSG2) & Autosomal dominant \\
\hline ARVD type 11 & $18 \mathrm{q} 12.1$ & Desmocollin-2(DSC2) & Autosomal dominant \\
\hline ARVD type 12 & $17 \mathrm{q} 21$ & Plakoglobin(JUP) & Autosomal dominant \\
\hline Naxos Disease & $17 \mathrm{q} 21$ & Plakoglobin(JUP) & Autosomal recessive \\
\hline
\end{tabular}

Table 5. Genes mutations associated with arrhythmogenic right ventricular dysplasia

Therapeutic options are limited due to the progressive course of ARVD. Competitive athletics should be avoided. It is generally believed that patients who meet the Task Force criteria for ARVD are at high risk for sudden cardiac death and should undergo ICD placement (Marcus et al., 2010). The role of electrophysiologic study and catheter ablation in ARVD is not well established, and but it is frequently used as a palliative measure in the setting of refractory ventricular tachycardia. Even though sotalol may be effective in patients with ARVD and ventricular tachycardia, heart transplantation is the choice for patients with refractory ventricular arrhythmias and progressive heart failure.

\subsection{Brugada syndrome}

Brugada syndrome is a genetic disease characterized by the occurrence of cardiac arrhythmias and sudden cardiac death in young individuals without evidence of structural heart disease. In fact, Brugada syndrome is associated with structural and functional abnormalities in the sodium channel. Because of the absence of structural heart abnormalities, Brugada syndrome is classified as a cardiac "channelopathy".

Genetic studies have determined that more than one gene is capable of causing this syndrome. Initially, mutations in only one gene, SCN5A, encoding the cardiac sodium channel, have been identified. Recently, flourishing gene mutations have been identified, such as mutations in the CACNA1c and CACNB2b genes, coding the calcium channels, and mutations in the KCNE3 gene, coding a subunit of the potassium channel (Antzelevitch et al., 2007; Delpón et al., 2008). There is some evidence showing that the electrical disorders associated with Brugada syndrome are mainly located in the right ventricle, particularly in the outflow tract of right ventricle. These patients typically present an ECG pattern characterized by ST segment elevation in the right precordial leads and a RBBB (Brugada et al., 1992).

Brugada syndrome is thought to be responsible for $4 \%$ to $12 \%$ of all sudden cardiac death and for up to $20 \%$ of sudden cardiac death in subjects without structural heart disease (Brugada et al., 2002). Sudden cardiac death associated with Brugada syndrome is caused by 
polymorphic ventricular tachycardia or ventricular fibrillation (Antzelevitch et al., 2006). Unfortunately, because the ECG is often dynamic and concealed, it is difficult to estimate the real prevalence of this disease (Nademanee et al., 1997). However, it is believed that the prevalence is less frequent in western countries and higher in Southeast Asia. In fact, Brugada syndrome is considered to be the major cause of natural death in young individuals in Thailand and the Philippines (Miyasaka et al., 2001; Donohue et al., 2008).

\section{Management of ventricular arrhythmias in the PICU}

The major issue for a pediatric intensivist regarding management of ventricular arrhythmias in the PICU is to cope with postoperative arrhythmias in patients with congenital heart diseases (CHD). In these patients, ventricular arrhythmias may occur in the early postoperative stage, caused by surgical procedure, or in the late stage, caused by a residual structural defect or scar tissue. In addition to early and late postoperative management, catheter ablation and implantable cardioverter-defibrillators (ICD) will also be discussed in this section.

\subsection{Early postoperative ventricular arrhythmias}

Early postoperative arrhythmias are defined as occurrence within the first 10 days after surgery. Patients with CHD who have hemodynamically unstable early postoperative ventricular tachycardia or ventricular fibrillation require immediate treatment, as suggested by the AHA guidelines for cardiopulmonary resuscitation. After stabilizing the airway and breathing, cardiopulmonary resuscitation should be started immediately (Kleinman et al., 2010). If the ventricular tachycardia persists after cardiopulmonary resuscitation, synchronized electrical cardioversion $(0.5-1.0 \mathrm{~J} / \mathrm{kg}$ ) should be administered. If a second shock $(2.0 \mathrm{~J} / \mathrm{kg})$ is unsuccessful, amiodarone or procainamide should be considered before administering a third shock. If the ventricular arrhythmias are successfully converted to sinus rhythm, potential causes for the ventricular arrhythmias must be identified. In patients without identifiable causes, close observation and administration of intravenous antiarrhythmic medications are necessary.

Amiodarone is the antiarrhythmic treatment for pulseless ventricular tachycardia recommended by the AHA Committee on Resuscitation guidelines. Amiodarone dosing should adhere to the following regimen for pediatric patients: an intravenous bolus administered at $5-10 \mathrm{mg} / \mathrm{kg}$ and then maintenance infusion at $5-15 \mathrm{mg} / \mathrm{kg} /$ day. The safety and efficacy of amiodarone has been documented in studies performed in children with CHD (Drago F et al., 1998). For patients with stable ventricular tachycardia, the dosage and desired levels of antiarrhythmic medications are shown in Table 6.

\begin{tabular}{|l|l|l|}
\hline \multicolumn{1}{|c|}{ Drug } & \multicolumn{1}{c|}{ Dosage } & \multicolumn{1}{c|}{ Desired level } \\
\hline Propranolol & $0.05-0.1 \mathrm{mg} / \mathrm{kg} / \mathrm{dose} \mathrm{q} 6 \mathrm{~h}$ & $20-150 \mathrm{ng} / \mathrm{ml}$ \\
\hline Procainamide & $\begin{array}{l}\text { Loading: } 5-15 \mathrm{mg} / \mathrm{kg} \text { in } 30 \mathrm{~min} \\
\text { Infusion: } 20-80 \mu \mathrm{g} / \mathrm{kg} / \mathrm{min}\end{array}$ & $4-8 \mu \mathrm{g} / \mathrm{ml}$ \\
\hline Lidocaine & $\begin{array}{l}\text { Loading: } 1-2 \mathrm{mg} / \mathrm{kg} \text { in } 30 \mathrm{~min} \\
\text { Infusion: } 10-50 \mu \mathrm{gg} / \mathrm{kg} / \mathrm{min}\end{array}$ & $1-5 \mu \mathrm{ml}$ \\
\hline Mexiletine & $3-5 \mathrm{mg} / \mathrm{kg} / \mathrm{dose} \mathrm{q} 8 \mathrm{~h}$ & $0.5-2.0 \mu \mathrm{g} / \mathrm{ml}$ \\
\hline Amiodarone & $\begin{array}{l}\text { Loading: } 5-10 \mathrm{mg} / \mathrm{kg} \text { in } 30 \mathrm{~min} \\
\text { Infusion: } 5-15 \mathrm{mg} / \mathrm{kg} / \text { day }\end{array}$ & $1.5-2.5 \mu \mathrm{g} / \mathrm{ml}$ \\
\hline
\end{tabular}

Table 6. Pharmacologic management of ventricular tachycardia in pediatric patients. 


\subsection{Late postoperative ventricular arrhythmias}

All patients with CHD who have undergone surgery are at risk of late postoperative ventricular arrhythmias. Therefore, they require follow-up for routine electrocardiography to evaluate the patient's conduction system for potential bundle branch block. Evaluation of sinus node function, abnormalities of ST and T wave, and premature ventricular contraction are important, since these abnormalities can trigger the occurrence of ventricular tachycardia or sudden death in these patients. In addition, Holter EKG can detect asymptomatic ventricular arrhythmias in patients with CHD, for example in up to $9 \%$ of postoperative TOF (Chandar et al., 1990). Furthermore, the electrophysiologic study with programmed ventricular stimulation may have a role in the risk stratification because some investigators found that the induction of polymorphic VT could predict VT and sudden cardiac death (Khairy et al., 2004). The most common types of CHD associated with postoperative ventricular arrhythmia are listed in Table 7.

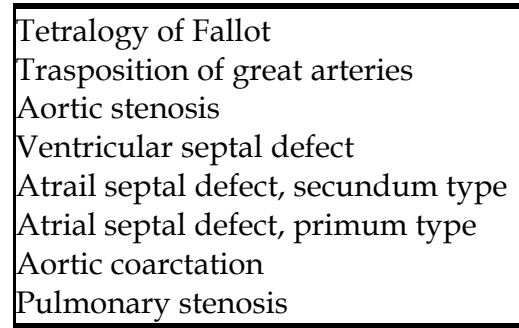

Table 7. Types of congenital heart defects commonly associated with postoperative ventricular arrhythmia.

\subsection{Catheter ablation}

There is some recent evidence addressing the role of catheter ablation in the treatment of ventricular tachycardia in CHD patients. For example, in a study of 10 patients with TOF who received noncontact mapping due to hemodynamically unstable ventricular tachycardia (Kriebelet al., 2007), ablation was achieved in eight patients and for all of them ventricular tachycardia was not inducible at the end of the procedure. Another study of electroanatomical contact mapping and catheter ablation in patients with ventricular tachycardia after repair of CHD demonstrated that isthmuses between patches and tricuspid annulus, right ventricular outflow tract, or pulmonary annulus were responsible for the reentrant tachycardias (Zeppenfeld et al., 2007). Ablation of these isthmuses abolished all ventricular tachycardias. Accordingly, there is a potential role for ventricular tachycardia ablation in patients after repair of CHD.

\subsection{Implantable cardioverter-defibrillators}

An implantable cardioverter-defibrillator (ICD) is recommended in CHD patients with a positive ventricular stimulation in the electrophysiology study. However, it is sometimes highly technical to implant a cardioverter-defibrillator transvenously in these patients due to their structural anomaly and small size of these patients. In addition, implanting a transvenous ICD system in patients with intracardiac shunting is not recommended, because the risk of thromboembolic events. The implantation of a transvenous ICD in patients younger than 8 years of age can be a high-risk procedure because of complications such as venous occlusion, infection or wound dehiscence because of limited prepectoral tissue. 
Surgical implantation is required when an ICD cannot be implanted transvenously. As such, the generator or device is implanted in the abdomen with the leads sewn into the epicardium. This surgical method is associated with some complications including postpericardiotomy syndrome, constrictive pericarditis, lead-induced trauma and lead failure (Stefanelli et al., 2002; Ketteringet al., 2004). Recent reports have described less invasive ways to implant an epicardial ICD in patients who are either too small or have mixing lesions (Cannon et al., 2006; Snyder et al., 2007). An additional problem is that patients may receive inappropriate shocks for sinus tachycardia due to improper programming. Accordingly, before programming an ICD in a patient with repaired CHD, patients should undergo exercise testing to determine their peak heart rate. Notably, some patients require adjuvant therapy with either nadolol or amiodarone, even with an ICD, to limit their peak heart rate and decrease chances of inappropriate shocks.

\section{Conclusions}

Ventricular tachycardias in the setting of PICU are a diverse group of rhythm disorders different from those seen in the adults with ischemic heart disease. They are not only different in ventricular substrates and etiologies, but also in the electrophysiologic mechanisms. Furthermore, ventricular arrhythmia after surgery for CHD requires a comprehensive evaluation including the clinical state of the patient, the cardiac anatomy, previous surgical history, and the electrophysiologic patterns of the arrhythmia. Most importantly, ventricular arrhythmia is an important cause of sudden death in the infants and children, so pediatric intensivists should be familiar with risk factors and emergent management of these life-threatening scenarios to ensure a better outcome.

\section{Acknowledgment}

We appreciate the assistance by Miss Hung Jui Feng to edit this manuscript.

\section{References}

Antzelevitch, C. Brugada syndrome. Pacing Clin Electrophysiol, Vol.29, No.10, (October2006), pp. 1130-1159, ISSN 1703-814

Antzelevitch, C.; Pollevick, GD.; Cordeiro, JM. Casis, O.; Sanguinetti, MC.; Aizawa, Y.; Guerchicoff, A.; Pfeiffer, R.; Oliva, A.; Wollnik, B.; Gelber, P.; Bonaros, EP. Jr.; Burashnikov, E.; Wu, Y.; Sargent, JD.; Schickel, S.; Oberheiden, R.; Bhatia, A.; Hsu, LF.; Haïssaguerre, M.; Schimpf, R.; Borggrefe, M. \& Wolpert, C, Loss-of-function mutations in the cardiac calcium channel underlie a new clinical entity characterized by ST-segment elevation, short QT intervals, and sudden cardiac death. Circulation, Vol.115, No.4, (Janurary2007), pp.442-9, ISSN 1722-4476

Arnestad, M.; Crotti, L.; Rognum, TO.; Insolia, R.; Pedrazzini, M.; Ferrandi, C.; Vege, A.; Wang, DW.; Rhodes, TE.; George, AL.; Jr. \& Schwartz, PJ. Prevalence of long QT syndrome gene variants in sudden infant death syndrome. Circulation, Vol.115, No.3, (Janurary2007), pp. 361-367, ISSN 17210-839

Brugada, P.; Brugada, J. Right bundle branch block, persistent ST segment elevation and sudden cardiac death: a distinct clinical and electrocardiographic syndrome. J Am Coll Cardiol, Vol.20, No.6, (November1992), pp. 391-1396, ISSN 1309-182 
Brugada, J.; Brugada, R.; Antzelevitch, C.; Towbin, J.; Nademanee, K. \& Brugada, P. Longterm follow-up of individuals with the electrocardiographic pattern of right bundle-branch block and ST-segment elevation in precordial leads V1 to V3. Circulation, Vol.105, No.1, (Janurary2002), pp. 73-78, ISSN 1177-2879

Cannon, BC.; Friedman, RA.; Fenrich, AL.; Fraser, CD.; McKenzie, ED. \& Kertesz, NJ. Innovative techniques for placement of implantable cardioverter-defibrillator leads in patients with limited venous access to the heart. Pacing Clin lectrophysiol, Vol.29, No.2, (February2006), pp. 181-187, ISSN 1649-2305

Chandar, JS.; Wolff, GS.; Garson, A.; Jr.; Bell, TJ.; Beder, SD.; Bink-Boelkens, M.; Byrum, CJ.; Campbell, RM.; Deal, BJ. \& Dick, M 2nd. et al. Ventricular arrhythmias in postoperative tetralogy of Fallot. Am J Cardiol, Vol.65, No.9(March1990), pp. 655661, ISSN 1689-93510

Corrado, D. \& Thiene, GC. Arrhythmogenic right ventricular cardiomyopathy/dysplasia: clinical impact of molecular genetic studies. Circulation, Vol.113, No.13, (April2006) pp. 1634-1647, ISSN 1658-5401

Curran, ME.; Splawski, I.; Timothy, KW.; Vincent, GM.; Green, ED. \& Keating, MT. A molecular basis for cardiac arrhythmia: HERG mutations cause long QT syndrome. Cell, Vol.80, No.5, (March1995), pp. 795-803, ISSN 7889-573

Cullen, S.; Celermajer, DS.; Franklin, RC.; Hallidie-Smith, KA. \& Deanfield, JE. Prognostic significance of ventricular arrhythmia after repair of tetralogy of Fallot: a 12-year prospective study. J Am Coll Cardiol, Vol.23, No.5, (April1994), pp. 1151-1155, ISSN 8144-782

Deanfield, JE.; McKenna, WJ. \& Hallidie-Smith, KA. Detection of late arrhythmia and conduction disturbances after correction of tetralogy of Fallot. Br Heart J, Vol.44, No.3, (September1980) , pp. 248-253, ISSN 742-6182

Delpón, E.; Cordeiro, JM.; Núñez, L.; Thomsen, PE.; Guerchicoff, A.; Pollevick, GD.; Wu, Y.; Kanters, JK.; Larsen, CT.; Hofman-Bang, J.; Burashnikov, E.; Christiansen, M. \& Antzelevitch, C. Functional effect of KCNE3 mutation and its role in the development of Brugada syndrome. Circ Arrhythm Electrophysiol. Vol.1, No.3, (August2008), pp. 209-218, ISSN 1912-2847

Dietl, CA.; Cazzaniga, ME.; Dubner, SJ.; Perez-Balino, NA.; Torres, AR. \& Favaloro, RG. Life-threatening arrhythmias and RV dysfunction after surgical repair of tetralogy of Fallot. Comparison between transventricular and transatrial approaches. Circulation, Vol.90, No.5, (November1994), pp. II7-12, ISSN 7955-286

Donohue, D.; Tehrani, F.; Jamehdor, R.; Lam, C. \& Movahed, MR. The prevalence of Brugada ECG in adult patients in a large university hospital in the western United States. Am Heart Hosp J. Vol.6, No.1, (November2008), pp. 48-50, ISSN 1825- 9122

Drago, F.; Mazza, A.; Guccione, P.; Mafrici, A.; Di Liso, G. \& Ragonese, P. Amiodarone used alone or in combination with propranolol: a very effective therapy for tachyarrhythmias in infants and children. Pediatr Cardiol, Vol.19, No.6, (November1998), pp. 445-449, ISSN 9770-567

Garson, A.; Jr.; Nihill, MR.; McNamara, DG. \& Cooley, DA. Status of adult and adolescent after repair of tetralogy of Fallot. Circulation, Vol.59, No.6, (June1979), pp. 12321240, ISSN 436-215 
Garson, A.; Jr. Gillette, PC.; Gutgesell, HP.\& McNamara, DG. Stressinduced ventricular arrhythmia after repair of tetralogy of Fallot. Am J Cardiol, Vol.46, No.6, (December1980), pp. 1006-1012, ISSN 7446-414

Garson, A.; Jr.; Randall, DC.; Gillette, PC.; Smith, RT.; Moak, JP.; McVey, P. \& McNamara, DG. Prevention of sudden death after repair of tetralogy of Fallot: Treatment of ventricular arrhythmias. J Am Coll Cardiol , Vol.6, No.1, (July1985), pp. 221-227, ISSN 4008-776

Gatzoulis, MA.; Till, JA.; Redington, AN. Depolarization-repolarization inhomogeneity after repair of tetralogy of Fallot. The substrate for malignant ventricular tachycardia? Circulation, Vol.95, No.2, (Janurary1997), pp. 401-404, ISSN 9008-456

Gatzoulis, MA.; Till, JA. Somerville, J. \& Redington, AN. Mechanoelectrical interaction in tetralogy of Fallot. QRS prolongation relates to right ventricular size and predicts malignant ventricular arrhythmias and sudden death. Circulation, Vol.92, No.2, (July1995), pp. 231-237, ISSN 7600-655

Gatzoulis, MA.; Balaji, S.; Webber, SA. Siu, SC.; Hokanson, JS.; Poile, C.; Rosenthal, M.; Nakazawa, M.; Moller, JH.; Gillette, PC.; Webb, GD. \& Redington, AN. Risk factors for arrhythmia and sudden cardiac death late after repair of tetralogy of Fallot: a multicentre study. Lancet, Vol.356, No.9234, (september2000), pp. 975-981, ISSN 11041-139825.

Gerull, B.; Heuser, A.; Wichter, T.; Paul, M.; Basson, CT.; McDermott, DA.; Lerman, BB.; Markowitz, SM.; Ellinor, PT.; MacRae, CA.; Peters, S.; Grossmann, KS.; Drenckhahn, J.; Michely, B.; Sasse-Klaassen, S.; Birchmeier, W.; Dietz, R.; Breithardt, G.; Schulze-Bahr, E. \& Thierfelder L. Mutations in the desmosomal protein plakophilin- 2 are common in arrhythmogenic right ventricular cardiomyopathy. Nat Genet, Vol.36, No.11, (November2004), pp. 1162-1164, ISSN 1548-9853

Jefferies, JL.; Towbin, JA. Dilated cardiomyopathy. Lancet, Vol.375, No.9716, (February2010), pp. 752-7622, ISSN 2018-9027

Jervell, A.; Lange-Nielsen, F. Congenital deaf-mutism, functional heart disease with prolongation of the Q-T interval, and sudden death. Am Heart J, Vol.54, No.1, (July1957), pp. 59-68. ISSN 1343-5203

Katz, NM.; Blackstone, EH.; Kirklin, JW.; Pacifico, AD. \& Bargeron, LM. Jr. Late survival and symptoms after repair of tetralogy of Fallot. Circulation, Vol.65, No.2, (February1982), pp. 403-410, .ISSN 7053-900

Kavey, RE.; Blackman, MS. \& Sondheimer, HM. Incidence and severity of chronic ventricular dysrhythmias after repair of tetralogy of Fallot. Am Heart J, Vol.103, No.3, (March1982) pp. 342-350, ISSN 7064-767

Kettering, K.; Mewis, C.; Dörnberger, V.; Vonthein, R.; Bosch, RF.; Seipel, L. \& Kühlkamp, V. Long-term experience with subcutaneous ICD leads: a comparison among three different types of subcutaneous leads. Pacing Clin Electrophysiol, Vol.27, No.10, (October 2004), pp. 1355-1361, ISSN 1551-1244

Khairy, P.; Landzberg, MJ.; Gatzoulis, MA.; Lucron, H.; Lambert, J.; Marçon, F.; Alexander, ME. \& Walsh, EP. Value of programmed ventricular stimulation after tetralogy of Fallot repair: a multi center study. Circulation, Vol.109, No.16, (April2004), pp. 1994-2000, ISSN 1505-1640 
Kleinman, ME.; Chameides, L.; Schexnayder, SM.; Samson, RA.; Hazinski, MF.; Atkins, DL.; Berg, MD.; de Caen, AR.; Fink, EL.; Freid, EB.; Hickey, RW.; Marino, BS.; Nadkarni, VM.; Proctor, LT.; Qureshi, FA.; Sartorelli, K.; Topjian, A.; van der Jagt, EW. \& Zaritsky, AL. Part 14: pediatric advanced life support: 2010 American Heart Association Guidelines for Cardiopulmonary Resuscitation and Emergency Cardiovascular Care. Circulation, Vol.122, No.18, (November2010), pp. S876-908. ISSN 2095-6230

Kriebel, T.; Saul, JP. Schneider, H.; Sigler, M. \& Paul, T. Noncontact mapping and radiofrequency catheter ablation of fast and hemodynamically unstable ventricular tachycardia after surgical repair of tetralogy of Fallot. J Am Coll Cardiol, Vol.50, No.22, (November2007), pp. 2162-2168, ISSN 1803-6455

Lee, MH.; Cheng, KI.; Jang, RC.; Hsu, JH.; Dai, ZK. \& Wu, JR. Tumour lysis syndrome developing during an operation. Anaesthesia, Vol.62, No.1, (Janurary2007), pp. 8587. ISSN 1715-6233

Lo, R.; Menzies, DJ.; Archer, H. \& Cohen, TJ. Complete heart block due to Lyme carditis. J Invasive Cardiol, Vol.15, No.6, (June2003), pp. 367-369, ISSN 1277-7681

Marcus, FI.; McKenna, WJ.; Sherrill, D.; Basso, C.; Bauce, B.; Bluemk, DA.; Calkins, H.; Corrado, D.; Cox, MG.; Daubert, JP.; Fontaine, G.; Gear, K.; Hauer, R.; Nava, A.; Picard, MH.; Protonotarios, N.; Saffitz, JE.; Sanborn, DM.; Steinberg, JS.; Tandri, H.; Thiene, G.; Towbin, JA.; Tsatsopoulou, A.; Wichter, T. \& Zareba, W. Diagnosis of arrhythmogenic right ventricular cardiomyopathy /dysplasia: proposed modification of the task force criteria. Circulation. Vol.121, No.13, (Arpil2010), pp. 1533-1541, ISSN 2017-2911

Matsuhashi, T.; Sato, T.; Aizawa, Y. \& Takatsuki, S. Recurrent Torsade de Pointes during mild hypothermia therapy for a survivor of sudden cardiac arrest due to druginduced long-QT syndrome. J Cardiovasc lectrophysiol, Vol.21, No.4, (April2010), pp. 462-463, ISSN: 1984-5813

McKoy, G.; Protonotarios, N. \& Crosby, A. Tsatsopoulou A, Anastasakis A, Coonar A, Norman M, Baboonian C, Jeffery S, McKenna WJ, Identification of a deletion in plakoglobin in arrhythmogenic right ventricular cardiomyopathy with palmoplantar keratoderma and woolly hair (Naxos disease). Lancet, Vol.355, No.9221, (June2000), pp. 2119-2124, ISSN 1090-2626

Merri, M.; Benhorin, J.; Alberti, M.; Locati, E. \& Moss, AJ. Electrocardiographic quantitation of ventricular repolarization. Circulation, Vol.80, No.5, (November1989), pp. 13011308, ISSN 2805-26

Miyasaka, Y.; Tsuji, H.; Yamada, K.; Tokunaga, S.; Saito, D.; Imuro, Y.; Matsumoto, N. \& Iwasaka, T. Prevalence and mortality of the Brugada-type electrocardiogram in one city in Japan. J Am Coll Cardiol, Vol.38, No.3, (September2001), pp. 771-774, ISSN 1152-7631

Moss, AJ.; Schwartz, PJ.; Crampton, RS.; Tzivoni, D.; Locati, EH.; MacCluer, J.; Hall, WJ.; Weitkamp, L.; Vincent,GM. \& Garson, A. Jr. The long QT syndrome. prospective longitudinal study of 328 families. Circulation, Vol.84, No.3, (September1991), pp. 1136-1144, ISSN 1884-444

Nademanee, K. Sudden unexplained death syndrome in Southeast Asia. Am J Cardiol, Vol.79, No.6A, (March1997), pp. 10-1, ISSN 9080-856 
Pilichou, K.; Nava, A.; Basso, C.; Beffagna, G.; Bauce, B.; Lorenzon, A.; Frigo, G.; Vettori, A.; Valente, M.; Towbin, J.; Thiene, G.; Danieli, GA. \& Rampazzo, A. Mutations in desmoglein-2 gene are associated to arrhythmogenic right ventricular cardiomyopathy. Circulation, Vol.113, No.9, (March2006), pp. 1171-1179, ISSN 16505173

Priori, SG.; Schwartz, PJ.; Napolitano, C.; Bloise, R.; Ronchetti, E.; Grillo, M.; Vicentini, A.; Spazzolini, C.; Nastoli, J.; Bottelli, G.; Folli, R.\& Cappelletti, D. Risk stratification in the long-QT syndrome. N Engl J Med, Vol.348, No.19, (May2003), pp.1866-1874, ISSN 1273-6279

Quattlebaum, TG.; Varghese, J.; Neill, CA. \& Donahoo, JS. Sudden death among postoperative patients with tetralogy of Fallot. A follow-up study of 243 patients for an average of 12 years. Circulation, Vol.54, No.2, (August1975), pp. 289-293, ISSN 9390-26

Romano, C.; Gemme, G. \& Pongiglione, R.. Aritmie cardiache rare dell'eta pediatrica. Clin Pediat, Vol.45, (September1963), pp. 656-683, ISSN 1415-8288

Rampazzo, A.; Nava, A.; Malacrida, S.; Beffagna, G.; Bauce, B.; Rossi, V.; Zimbello, R.; Simionati, B.; Basso, C.; Thiene, G. Towbin, JA \& Danieli, GA. Mutation in human desmoplakin domain binding to plakoglobin causes a dominant form of arrhythmogenic right ventricular cardiomyopathy. Am J Hum Genet, Vol.171, No.5, (November2002), pp. 1200-1206, ISSN 1237-3648

Schwartz, PJ.; Periti, M. \& Malliani, A. The long Q-T syndrome. Am Heart J, Vol.89, No.3, (March1975), pp.37 8-390, ISSN 234-667

Schwartz, PJ.; Southall, DP.; Valdes-Dapena, M. \& Eds. The sudden infant death syndrome: cardio-respiratory mechanisms and interventions. Ann NY Acad Sci, Vol.533, (March 1988), pp.1-:474, ISSN 3421-616

Schwartz, PJ.; Stramba-Badiale, M.; Segantini, A.; Austoni, P.; Bosi, G.; Giorgetti, R.; Grancini, F.; Marni, ED.; Perticone, F.; Rosti, D. \& Salice, P. Prolongation of the QT interval and the sudden infant death syndrome. N Engl J Med, Vol.338, No.24, (June1998), pp. 1709-1714, ISSN 9624-190

Schwartz, PJ.; Garson, A, Jr.; Paul, T.; Stramba-Badiale, M.; Vetter, VL. \& Wren, C. European Society of Cardiology: Guidelines for the interpretation of the neonatal electrocardiogram. A task force of the European Society of Cardiology. Eur Heart J, Vol.23, No.17, (September2002), pp. 1329-1344, ISSN 1226-9267

Schaefer, TJ.; Wolford, RW. Disorders of potassium. Emerg Med Clin North Am, Vol.23, No.3, (August2005), pp. 723-747 ISSN 1598-2543

Schwartz, PJ.; Spazzolini, C.; Crotti, L.; Bathen, J.; Amlie, JP.; Timothy, K.; Shkolnikova, M.; Berul, CI.; Bitner-Glindzicz, M.; Toivonen, L.; Horie, M.; Schulze-Bahr, E \& Denjoy, I. The Jervell and Lange-Nielsen Syndrome. Natural history, molecular basis, and clinical outcome. Circulation, Vol.113, No.6, (February2006), pp. 783-790, ISSN 16461811

Snyder, CS.; Lucas, V.; Young, T.; Darling, R.; Dalal, G. \& Davis, JE. Minimally invasive implantation of a cardioverter-defibrillator in a small patient. J Thorac Cardiovasc Surg, Vol.133, No.2, (May2007), pp. 1375-1376, ISSN 1746-7466

Stefanelli, CB.; Bradley, DJ.; Leroy, S.; Dick, M 2nd.; Serwer, GA. \& Fischbach, PS. Implantable cardioverter defibrillator therapy of life-threatening arrhythmias in 
young patients. J Interv Card Electrophysiol, Vol.6, No.3, (July2002), pp. 235-244, ISSN 1215-4326

Storm, C.; Hasper, D.; Nee, J.; Joerres, A.; Schefold, JC.; Kaufmann, J. \& Roser, M. Severe QTc prolongation under mild hypothermia treatment and incidence of arrhythmias after cardiac arrest--a prospective study in 34 survivors with continuous Holter ECG. Resuscitation. Vol.82, No.7, (July2011), pp. 859-862. ISSN 2148-2009

Stramba-Badiale, M.; Spagnolo, D.; Bosi, G. \& Schwartz, PJ. Are gender differences in QTc present at birth? MISNES Investigators. Multicenter Italian Study on Neonatal Electrocardiography and sudden infant death syndrome. Am J cardiol, Vol.75, No.17, (June1995), pp. 1277-1278, ISSN 7778-558

Vetter, VL.; and Horowitz, LN. (1982) Electrophysiologic residua and sequelae of surgery from congenital heart defects. Am J Cardiol, Vol.50, No.3, (September1982), pp. 588604, ISSN 7051-800

Wang, Q.; Shen, J.; Splawski, I.; Atkinson, D.; Li, Z.; Robinson, JL.; Moss, AJ.; Towbin, JA. \& Keating, MT. SCN5A mutations associated with an inherited cardiac arrhythmia, long QT syndrome. Cell, Vol.80, No.2, (March1995), pp. 805-811, ISSN 7889-574

Wang, Q.; Curran, ME.; Splawski, I,.; Burn, TC.; Millholland, JM.; VanRaay, TJ.; Shen, J.; Timothy, KW.; Vincent, GM.; de Jager, T.; Schwartz, PJ.; Towbin, JA.; Moss, AJ.; Atkinson, DL.; Landes, GM.; Connors, TD. \& Keating, MT. Positional cloning of a novel potassium channel gene: KVLQT1 mutations cause cardiac arrhythmias. Nat Genet, Vol.12, No.1, (Janurary1996), pp. 17-23, ISSN 8528-244

Ward, OC. A new familial cardiac syndrome in children. J Ir Med Assoc, Vol.54, (April1964), pp. 103-106, ISSN 1413-6838

Wolfe, RR.; Driscoll, DJ.; Gersony, WM.; Hayes, CJ.; Keane, JF.; Kidd, L.; O'Fallon, WM.; Pieroni, DR. \& Weidman, WH. Arrhythmias in patients with valvar aortic stenosis, valvar pulmonary stenosis, and ventricular septal defect. Results of 24-hour ECG monitoring. Circulation, Vol.87, No.2, (February1993), pp. I89-101, ISSN 8425-327

Zeppenfeld, K.; Schalij, MJ.; Bartelings, MM.; Tedrow, UB.; Koplan, BA. Soejima, K. \& Stevenson, WG. Catheter ablation of ventricular tachycardia after repair of congenital heart disease: electroanatomic identification of the critical right ventricular isthmus. Circulation, Vol.116, No.20, (November2007), pp. 2241- 2252, ISSN 1796-7973 


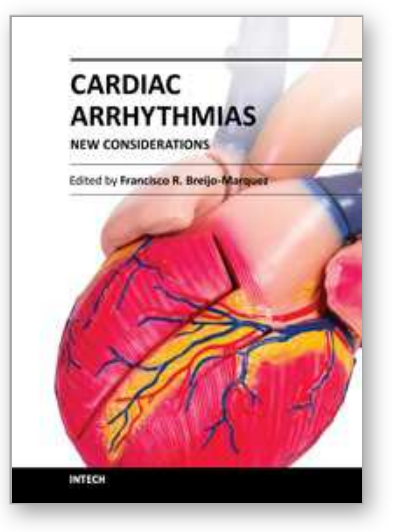

\author{
Cardiac Arrhythmias - New Considerations \\ Edited by Prof. Francisco R. Breijo-Marquez
}

ISBN 978-953-51-0126-0

Hard cover, 534 pages

Publisher InTech

Published online 29, February, 2012

Published in print edition February, 2012

The most intimate mechanisms of cardiac arrhythmias are still quite unknown to scientists. Genetic studies on ionic alterations, the electrocardiographic features of cardiac rhythm and an arsenal of diagnostic tests have done more in the last five years than in all the history of cardiology. Similarly, therapy to prevent or cure such diseases is growing rapidly day by day. In this book the reader will be able to see with brighter light some of these intimate mechanisms of production, as well as cutting-edge therapies to date. Genetic studies, electrophysiological and electrocardiographyc features, ion channel alterations, heart diseases still unknown , and even the relationship between the psychic sphere and the heart have been exposed in this book. It deserves to be read!

\title{
How to reference
}

In order to correctly reference this scholarly work, feel free to copy and paste the following:

Jong-Hau Hsu, Jiunn-Ren Wu, Zen-Kong Dai and I-Chen Chen (2012). Approach to Ventricular Arrhythmias in the Pediatric Intensive Care Unit, Cardiac Arrhythmias - New Considerations, Prof. Francisco R. BreijoMarquez (Ed.), ISBN: 978-953-51-0126-0, InTech, Available from: http://www.intechopen.com/books/cardiacarrhythmias-new-considerations/approach-to-ventricular-arrhythmias-in-the-pediatric-intensive-care-unit

\section{INTECH}

open science | open minds

\section{InTech Europe}

University Campus STeP Ri

Slavka Krautzeka 83/A

51000 Rijeka, Croatia

Phone: +385 (51) 770447

Fax: +385 (51) 686166

www.intechopen.com

\section{InTech China}

Unit 405, Office Block, Hotel Equatorial Shanghai

No.65, Yan An Road (West), Shanghai, 200040, China

中国上海市延安西路65号上海国际贵都大饭店办公楼 405 单元

Phone: +86-21-62489820

Fax: +86-21-62489821 
(C) 2012 The Author(s). Licensee IntechOpen. This is an open access article distributed under the terms of the Creative Commons Attribution 3.0 License, which permits unrestricted use, distribution, and reproduction in any medium, provided the original work is properly cited. 